\title{
Perkembangan Sosial, Emosi, Moral Anak, dan Implikasinya terhadap Pembentukan Sikap Sosial Siswa Sekolah Dasar
}

Received:

$29 / 12 / 2022$

Accepted:

$30 / 12 / 2022$

Published:

$31 / 12 / 2022$

\author{
${ }^{1}$ Ani Siti Anisah, ${ }^{2}$ Sapriya, ${ }^{3}$ Kama Abdul Hakam, ${ }^{4}$ Ernawulan \\ ${ }^{1}$ Universitas Garut, Garut, Indonesia \\ 2,3,4 Universitas Pendidikan Indonesia, Bandung, Indonesia \\ ${ }^{1}$ sitianisah@uniga.ac.id
}

\begin{abstract}
This study aims to determine (1) the characteristics of social, emotional, and moral development in elementary school children, and (2) the implications of children's social, emotional, and moral development on the formation of social attitudes in elementary school children. The research method used in this study is a literature. The results showed that the characteristics of social, emotional, and moral development of elementary school children were aware of the social roles, religion, race, and socioeconomic status of their peers, accepted cultural stereotypes, and adult attitudes towards their status, thus creating group awareness in their social environment. These characteristics will persist until late childhood and will continue until they are adults if educators provide a stimulus in continuing their mature developmental tasks. The stimulus is in the form of guidance, direction, and providing a good and healthy socio-cultural environment in social, emotional, and moral development so that it has implications for the formation of good social attitudes. For children's socialization skills to improve, the task of educators is to guide and direct them to learn to accept and carry out responsibilities, learn to compete with others, learn good social behavior, learn to work together, learn from adults, and learn with peers, learn to adapt themselves with group standards, learn to play to develop physical, learn to share, and learn sportsmanship. The most important thing is good parenting from parents as the first madrasa for children informing children with noble character as a form of good social attitude in society.
\end{abstract}

Keywords: Children's Social, Emotional, Moral Development; Social Attitude; Elementary School Students

\begin{abstract}
Abstrak
Penelitian ini bertujuan untuk (1) mengetahui karakteristik perkembangan social, emosional dan moral pada anak usia sekolah dasar, dan (2) untuk mengetahui implikasi perkembangan social, emosional, dan moral anak terhadap pembentukan sikap social pada anak usia sekolah dasar. Metode penelitian yang digunakan dalam penelitian ini adalah studi pustaka dengan teknik pengumpulan data melalui lembar checklis untuk memilih sumber primer dan sumber sekunder yang akan dijadikan rujukan. Hasil penelitian menunjukkan bahwa karakteristik perkembangan social, emosi, dan moral anak sekolah dasar sudah menyadari akan peran sosial, agama, ras, dan status social ekonomi dari teman sebayanya, menerima stereotif budaya dan sikap dewasa terhadap statusnya sehingga menimbulkan kesadaran
\end{abstract}


kelompok dalam bersikap di lingkungan sosialnya. Karakteristik tersebut akan menetap sampai masa kanak-kanak akhir dan akan terus berlanjut sampai mereka dewasa jika pendidik memberikan stimulus dalam melanjutkan tugas perkembangannya secara matang. Stimulus tersebut berupa bimbingan, arahan, dan memberikan lingkungan social budaya yang baik dan sehat dalam perkembangan social, emosi, dan moralnya sehingga berimplikasi pada pembentukan sikap social yang baik. Agar kemampuan sosialisasi anak meningkat tugas pendidik adalah membimbing dan mengarahkan mereka untuk belajar menerima dan melaksanakan tanggung jawab, belajar bersaing dengan orang lain, belajar berprilaku social yang baik, belajar bekerja sama, belajar dari orang dewasa, belajar kepada kelompok sebaya, belajar menyesuaikan diri dengan standar kelompok, belajar bermain mengembangkan fisiknya, belajar berbagi, dan belajar bersikap sportif. Yang paling utama adalah pola asuh yang baik dari orang tua sebagai madrasah pertama bagi anak-anaknya dalam membentuk anak yang berakhlakul karimah sebagai wujud sikap social yang baik dalam lingkungan masyarakat.

Kata kunci: Perkembangan Sosial, Emosi, Moral Anak; Sikap Sosial; Siswa Sekolah Dasar

\section{Pendahuluan}

Sikap social (social attitudes) merupakan kesadaran dalam individu yang mempengaruhi terhadap lingkungan social. Sikap social tidak terbentuk secara alamiah dan bukan merupakan pewarisan sifat. Sikap dapat terbentuk sepanjang kehidupan manusia itu sendiri (Saifudin, 2016) yang didasarkan atas adanya stimulus dan pengaruh dari lingkungan social dan kebudayaan yaitu lingkungan keluarga, sekolah, norma, golongan agama, dan adat istiadat sebagai stimulus terbesar dalam membentuk sikap (Ahmadi, 2007). Seorang anak tumbuh dan berkembang di lingkungan keluarga adalah bagian dari proses interaksi bersama orang-orang disekitarnya dalam membentuk sikap melalui proses belajar sosial, yaitu proses dimana individu memperoleh informasi, tingkah laku, atau sikap baru dari orang lain (Listyaningrum, 2018).

Anak usia sekolah dasar usia 6-12 tahun sedang mengalami perkembangan pada berbagai aspek mulai dari fisik, motoric, kepribadian, social, emosi, kognitif dan bahasa, dan moral keagamaan (Henri, 2018). Pada tahap masa kanak-kanak akhir inilah sikap social mulai terbentuk, karena secara psikis kondisi anak dipengaruhi oleh penyesuaian pribadi dan social. Masa usia sekolah ini sebagai masa yang sangat penting, mereka dihadapkan pada suasana baru yang dituntut agar bisa menyesuaikan diri dalam bersosialisasi dengan masyarakat meski dalam lingkup kecil (Wiyani, 2013), karena pada usia ini disebut sebagai usia berkelompok dimana anak akan menunjukkan sikap social yang diperlukan dalam proses interaksi sosialnya (Hurlock, 1980).

Sikap social yang ditunjukkan anak dalam berinteraksi dan bersosialisasi adalah mampu menunjukkan perilaku jujur, disiplin, tanggung jawab, peduli, toleransi, gotong royong, santun, dan percaya diri dalam berinteraksi secara efektif dengan lingkungan social (Kemendikbud, 2013). Ketidak sempurnaan sikap social yang ditunjukkan anak 
ketika berinteraksi dengan kelompoknya disebabkan oleh tidak berhasilnya mereka dalam menyelesaikan tugas-tugas perkembangannya.

Dewasa ini tidak sedikit pendidik yang tidak memahami pola pertumbuhan dan perkembangan peserta didik. Masih banyak guru yang belum memahami peserta didiknya dan solusi apa yang harus ditindaklanjuti dalam mengatasi kekurangan anak didiknya (Syukri et al., 2021). Padahal aspek-aspek perkembangan pada diri siswa sangat penting difahami untuk kelancaran proses pembelajaran. Kurang fahamnya pendidik tentang perkembangan peserta didik akan menimbulkan beberapa hambatan dalam proses pembelajaran, dalam aspek kognitif anak sulit menerima materi yang disampaikan guru (Sabani, 2019). Dalam aspek social, emosi, dan moral, kegagalan dalam mencapai tugas perkembangan pada anak sekolah dasar akan menimbulkan perilaku menyimpang (delinquency) seperti membolos dari sekolah, malas belajar, dan keras kepala, tidak disiplin (Santrock, 2003), kasus bullying yang dilakukan anak SD baik sebagai pelaku maupun korban tentu akan menimbulkan resiko yang sangat fatal bagi mereka (Mandira \& Stoltz, 2021), kemudian muncul istilah cyberbullying merupakan perundungan yang dilakukan di media social sudah sangat menghawatirkan karena dampaknya sangat jelas secara tidak langsung membunuh karakter seseorang (Peled, 2019), sikap intoleran, tidak memiliki etika yang baik (Sumani, 2019), bahkan siswa SD di Bukittinggi dengan agresif dan marah memukul teman perempuannya dan ditonton teman lainnya (https://new.detik.com, 2014). Kenakalan lain ditunjukkan dengan perkelahian, berkata kotor, tidak sopan, brutal, mengganggu orang, mencuri, dan menimbulkan kerusuhan (Berlian et al., 2015). Hal itu disebabkan oleh perkembangan social, emosi, dan moral anak dipengaruhi oleh lingkungan yang tidak mendukung dalam memotivasi mereka untuk membentuk sikap yang sesuai dengan norma-norma social.

Aspek perkembangan social, emosi, dan moral anak seyogyanya menjadi focus perhatian para pendidik, supaya semua aspek perkembangan yang ada pada diri anak bisa di stimulus dan berkembang secara optimal. Tugas perkembangan yang gagal akan berakibat fatal, tidak saja anak mengalami hambatan dalam perkembangan pada masa perkembangan di usia berikutnya, tetapi anak juga akan mengalami kesulitan dalam menghadapi kehidupan di masa yang akan datang (Syaodih, 2011). Orang tua dan guru selayaknya berperan dan bertanggung jawab terhadap tumbuh kembang anak dalam berbagai aspek melalui penerapan pola asuh yang baik agar terbentuk karakter yang baik pada diri anak di masa dewasanya (Anisah, 2011).

Melalui tulisan ini, para pendidik diharapkan mendapatkan penguatan pengetahuan terkait perkembangan social, emosi, dan moral anak yang akan berimplikasi pada sikap social siswa dalam hal ini, focus kajian pada siswa sekolah dasar. Penelitian ini diharapkan akan memberikan kontribusi kepada para pendidik (guru dan orang tua) sebagai bahan referensi dalam melaksanakan tugasnya sebagai pendidik, pengajar, pembimbing yang harus mengarahkan, dan memperhatikan sikap, tingkah laku, dan perbuatan anak didiknya agar mencapai kematangan tidak hanya 
pada aspek kognitif, tetapi juga mencapai kematangan dalam aspek social, emosi, dan moralnya sebagai bekal mereka untuk bisa berinteraksi dalam lingkungan sosialnya yang ditunjukkan melalui sikap social yang baik yang sesuai dengan norma-norma yang berlaku di masyarakat.

\section{Metode Penelitian}

Penelitian ini merupakan penelitian pustaka atau literature review dengan fokus masalah pada implikasi perkembangan social emosi dan moral anak terhadap pembentukan sikap social siswa sekolah dasar. Desain penelitian ini adalah penelitian kualitatif dengan menyediakan lembar checklis untuk menyeleksi beberapa sumber primer dan sumber sekunder yang penulis gunakan dalam studi literature ini. Adapun tahapan-tahapan yang dilakukan dalam memilih dan memilah data sebagai sumber primer ataupun sekunder, pertama: penulis menentukan tema penelitian terkait dengan sikap social siswa, kedua; mencari dan mengumpulkan berbagai sumber di berbagai website mulai dari Google Scholar, Science Direct, Perpustakaan Nasional, SAGE, dan website lainnya, ketiga: penulis mengklasifikasikan beberapa sumber yang relevan dengan topik penelitian dan sebagai sumber rujukan utama ditempatkan di sumber primer, dan sumber-sumber lainnya (sumber sekunder) sebagai pelengkap dalam mendukung tulisan ini, keempat; menyusun artikel sebagai hasil analisis dan sintesis.

\section{Hasil}

Perkembangan peserta didik berbeda setiap tahapannya. Factor yang mempengaruhi perkembangan (development) adalah bertambahnya keterampilan (skill) dalam struktur dan fungsi tubuh ke arah yang lebih kompleks dan matang. Tidak hanya pada perkembangan fisik, kognitif dan bahasa, aspek social emosi dan moral seseorang akan mengalami perkembangan seiring dengan pertumbuhannya. Menurut Santrock (Desmita, 2005) ada tiga bidang utama perkembangan manusia tidak bisa berdiri sendiri dan saling berkaitan karena jika salah satu dimensi perkembangan terganggu akan mengganggu dimensi lainnya. Dimensi perkembangan itu diantaranya, perkembangan fisik (biologis), kognitif, dan psikososial (sosioemosional).

Dalam pembahasan ini, akan difokuskan pada perkembangan social, emosi, dan moral anak sekolah dasar.

\section{Perkembangan Social}

Sebagai makhluk social, seseorang akan mengalami proses interaksi dan sosialisasi dengan makhluk lainnya. Perkembangan social merupakan kematangan yang dicapai sebagai proses hubungan social (Sitorus, 2017) atau jalinan interaksi anak dengan orang lain, mulai dari orang tua, saudara, teman sebaya, hingga masyarakat secara luas (Suyadi, 2010) yang dimaknai sebagai proses belajar untuk menyesuaikan diri terhadap norma-norma yang berlaku dalam proses penyesuaian diri dan bersosialisasi di lingkungan masyarakat (Assingkily \& Hardiyati, 2019). 
Perkembangan social sudah muncul pada masa awal kanak-kanak atau disebut masa prakelompok (Hurlock, 1980). Dasar untuk sosialisasi diletakkan dengan meningkatnya hubungan antar anak dengan teman-teman sebaya dari tahun ke tahun. Meskipun pada tahap ini anak lebih menunjukkan sikap egosentrisnya, masa wal kanakkanak bisa juga bersikap ramah dan aktif secara social jika pendampingan dari orang dewasa berhasil. Dan Hurlock (1980) meramalkan jika sejak usia 2,5 anak bisa bersikap social yang baik, maka anak akan terus bersikap seperti itu sampai usia 7.5 tahun.

Pada masa kanak-kanak akhir (usia 6-12 tahun) para pendidik memberi label sebagai anak usia sekolah dasar, (Hurlock, 1980) atau middle childhood (Sabani, 2019). Pada masa ini disebut sebagai usia matang untuk belajar. Anak mampu menguasai kecakapan-kecakapan baru yang diberikan guru di sekolah. Disamping itu menurut Sabani (2019) sikap mereka terhadap keluarga tidak lagi egosentris, tetapi bisa bersikap objektif dan empiris terhadap dunia luar sehingga masa ini disebut periode intelektual atau masa keserasian sekolah.

Anak usia sekolah dasar dibedakan pada kelas rendah dan kelas tinggi. Masingmasing memiliki karakteristik yang berbeda. Karakteristik social anak sekolah dasar usia rendah usia 6-8 tahun (kelas 1, 2,3) memiliki sifat diantaranya: (1) hasrat besar terhadap hal-hal yang bersifat drama; (2) berkhayal dan suka meniru; (3) gemar akan keadaan alam; (4) senang akan cerita-cerita; (5) sifat pemberani; (6) senang mendapat pujian. Sementara karakteristik sosial anak kelas tinggi usia 9-12 tahun (kelas 4, 5, 6) memiliki sifat: (1) tidak suka pada hal-hal yang bersifat drama; (2) gemar pada lingkungan social; (3) senang pada cerita-cerita lingkungan social; (4) sifat pemberani tetapi masih menggunakan logika.

Secara umum, siswa sekolah dasar memiliki karakteristik: 1) belajar membentuk sikap yang sehat terhadap dirinya sendiri sebagai makhluk biologis, 2) belajar bergaul dengan teman sebaya, 3) belajar memainkan peranan sesuai dengan jenis kelaminnya, 4) belajar keterampilan dasar dalam membaca, menulis dan berhitung, 5) mengembangkan kata hati, 6) belajar mengembangkan konsep sehari-hari, 7) belajar membperoleh kebebasan yang bersifat pribadi, 8) mengembangkan sifat positif, 9) mempunyai sifat patuh terhadap aturan, 10) kecenderungan memuji diri sendiri, 11) suka membandingkan diri dengan orang lain, 12) jika tidak bisa menyelesaikan tugas, maka dianggap tidak penting, 13) realistis dan rasa ingin tahu yang besar, 14) kecenderungan untuk melakukan kehidupan yang bersifat praktis dan nyata, 15) memiliki minat kepada hal-hal yang khusus seperti mata pelajaran atau minat dan bakat, 16) gemar membentuk kelompok teman sebaya untuk bermain bersama (Sabani, 2019; Wiratman et al., 2019).

Karakteristik anak sekolah dasar sering disebut sebagai usia berkelompok karena ditandai dengan adanya minat terhadap aktivitas teman-teman dan meningkatnya keinginan untuk diterima sebagai anggota kelompok. Kematangan aspek social pada anak menurut Hurlock (1980) bisa ditingkatkan melalui keanggotaan kelompok melalui beberapa cara: 1) belajar menerima dan melaksanakan tanggungjawab, 2) belajar bersaing dengan orang lain, 3) belajar perilaku social yang baik, 4) belajar bekerja sama, 


\section{4 | Ani Siti Anisah, Sapriya, Kama Abdul Hakam, dan Ernawulan Syaodih}

5) belajar dari orang-orang dewasa, 6) belajar kepada kelompok, 7) belajar menyesuaikan diri dengan standar kelompok, 8) belajar bermain dan olah raga, 9) belajar berbagi rasa dengan orang lain, 10) belajar bersikap sportif.

\section{Perkembangan Emosi}

Perkembangan emosi pada anak usia Sekolah Dasar dimulai pada usia 5-6 tahun. pada usia ini anak sudah mulai mempelajari kaidah-kaidah aturan yang berlaku, bampu mempelajari konsep keadilan, mampu menjaga rahasia sebagai kemampuan anak dalam belajar menyembunyikan informasi. Pada usia 6 tahun mereka sudah memahami konsep emosi yang lebih kompleks seperti cemburu, merasa bangga, sedih, dan kehilangan, tetapi masih kesulitan untuk mengontrol dan mengarahkan ekspresi emosionalnya. pada usia 7-8 tahun, perkembangan emosi sudah terinternalisasi dan sudah mengekspresikan rasa malu dan bangga. sehingga mereka bisa mengungkapkan perasaannya secara verbal terhadap konflik emosi yang dirasakannya (Ladubasari, Erna; Sriastria, 2012). Pada usia 9-10 tahun, anak sudah mampu mengatur ekspresi emosi positif maupun negative dalam situasi social dan dapat merespon distress emosional yang terjadi pada orang lain dan bisa belajar bagaimana meredam emosi. Pada usia 11-12 tahun anak sudah bisa belajar memahami keberagaman emosi yang dirasakan.

\section{Perkembangan moral}

Dalam pandangan teori psikoanalisa, perkembangan moral merupakan proses internalisasi norma-norma masyarakat dan dipengaruhi oleh kematangan biologis individu. Sementara teori bihavioristik memandang bahwa perkembangan moral merupakan rangkaian stimulus respon yang dipelajari anak berupa reward and punishment yang sering dialami anak (Latifa, 2017).

Pada masa awal kanak-kanak perkembangan moral masih dalam tingkat rendah, disebabkan oleh perkembangan intelektual anak belum mencapai titik dimana anak dapat mempelajari dan menerapkan prinsip-prinsip abstrak tentang benar dan salah, dan tidak memiliki dorongan untuk mengikuti peraturan-peraturan karena belum mengerti manfaat sebagai anggota kelompok social (Hurlock, 1980).

Pada masa akhir kanak-kanak (usia sekolah dasar), kode moral sangat dipengaruhi oleh standar moral dari kelompok dimana anak mampu mengidentifikasi diri. anak akan mengikuti standar moral anggota kelompoknya tanpa meninggalkan kode moral yang berasal dari keluarganya. pada periode ini, kode moral anak berangsur menuju kode moral masa remaja. Hurlock (1980) menegaskan bahwa anak yang memiliki IQ tinggi akan memiliki kematangan moral lebih tinggi dibanding anak yang IQ nya dibawah mereka. Peran disiplin sangat penting dalam perkembangan moral anak periode ini, karena disiplin adalah masalah serius bagi anak yang lebih dewasa. Kohlberg memperluas tahapan perkembangan moral Piaget dengan memasukkan dua tahapan tingkat perkembangan yaitu tingkat "moralitas prakonvensional" orientasinya kepada patuh dan hukuman dalam arti menilai benar salahnya perbuatan. 


\section{Dampak Tugas Perkembangan Anak Tidak Berhasil}

Tugas perkembangan pada masa akhir anak ini tidak terletak pada tanggung jawab orang tua seperti pada masa awal kanak-kanak. Pada masa ini, tugas-tugas perkembangan anak menjadi tanggung jawab guru dan teman sebaya nya. Pengembangan sikap-sikap terhadap kelompok social dan lembaga merupakan tanggung jawab orang tua dan guru. Orang tua merupakan peletak dasar bagaimana anak mampu menyesuaikan diri dengan teman sebaya, dan pentingnya berkelompok untuk memberikan kesempatan bagi anak agar memperoleh pengalaman belajar di luar lingkungan keluarga.

Pada aspek social, tidak berhasilnya tugas perkembangan anak akan berakibat kesepian, karena merasa tidak popular diantara teman-temannya sehingga tidak akan mendapatkan pengakuan dari teman sebayanya. Sikap agresif akan muncul jika anak dipaksa untuk bermain idak sesuai dengan jenis kelaminnya, sehingga merasa memiliki kekuatan dan terjadi pertentangan dengan teman sebayanya dan akibatnya terjadi penolakan. Penolakan itu berkaibat fatal terhadap perkembangan social mereka, karena jika perkembangan sosialnya kurang baik, maka anak tidak memiliki pengalaman social yang baik dan tidak memiliki kesempatan untuk belajar berperilaku secara social. Selain itu, anak yang tidak berhasil melaksanakan tugas perkembangannya akan memunculkan imajinasi dengan teman khayalan. Hal itu menunjukkan anak tidak bisa bersosialisasi dengan baik, tetapi sebaliknya, jika anak terlalu banyak menghabiskan waktu dengan teman-temannya dikhawatirkan mereka tidak bisa mentreatmen diri ketika sedang sendiri.

Pada aspek emosi, akan terlihat dominasi emosi anak kurang baik dan jika tidak diberikan pola asuh yang baik, maka akan mendorong terhadap perkembangan watak yang kurang baik (Hurlock, 1980). Pada aspek emosi, penyesuaian pribadi dan social, menunjukkan ketidakmampuan melakukan "emphatic complex" yaitu ikatan emosional antar individu dan orang lain. Hal ini disebabkan oleh tidak mendapatkan kehangatan dan kelekatan dari orang terdekat seperti seorang ibu atau pengganti ibu, sehingga tidak mendapatkan kasih sayang yang kuat dan akan memunculkan ketergantungan emosional kepada satu orang.

Pada aspek moral, masa awal kanak-kanak belum bisa menerapkan disiplin secara konsisten sehingga memperlambat proses penyesuaian diri anak. Kemudian jika anak melakukan kesalahan dan tidak ditegur, maka mereka akan mempertahankan perilaku mereka. Begitupun jika konteks hukuman terus menerus menjadi bagian dari pola asuh anak, maka anak bukannya menyadari kesalahannya tetapi mereka akan semakin menunjukkan kecenderungan akan amarah, berontak dan menantang. Hukuman hendaknya tidak terlalu sering dilakukan, si anak tidak akan memiliki rasa peka terhadap tujuan hukuman. Jadi ketika menerapkan disiplin otoriter, maka akan berdampak kepada sulitnya mendorong pengendalian diri secara internal. 


\section{Diskusi}

Implikasi Perkembangan Sosial, Emosi, dan Moral Anak Terhadap Pembentukan Sikap Sosial Siswa Sekolah Dasar

Sikap social merupakan proses individu dalam melatih kepekaan terhadap rangsangan-rangsangan yang ditimbulkan dalam proses interaksi social . Rangsangan tersebut berupa fakta atau peristiwa yang direspon secara objektif. Sikap social merupakan bagian dari nilai-nilai karakter yang menetap dalam diri individu yang terdiri dari, sikap jujur, disiplin, tanggung jawab, peduli, toleransi, gotong royong, santun, dan percaya diri (Ahsani, 2020).

Sikap social muncul sebagai konstelasi skema perkembangan aspek social, emosional, dan moral. Skema tersebut tidak bekerja alamiah, tetapi perlu adanya stimulus agar berkembang secara optimal. Lingkungan sekolah dan keluarga dianggap sebagai mikrosistem proksimal yang penting untuk pengembangan social dan perilaku anak (Wang et.al., 2021). Pengalaman interaksional secara positif antara rumah dan ruang kelas meningkatkan kualitas perkembangan aspek social emosional anak. Sekolah harus memainkan perannya dalam membekali anak dengan pemahaman dan kesadaaran moral melalui modelling dalam membentuk identitas moral mereka (Puspitasari et al., 2021)

Optimalisasi pengembangan aspek social, emosi, dan moral anak selama di rumah harus mendapatkan parenting dari orang tua yang sesuai dengan tuntunan Al Qur'an dan Sunnah (Anisah, 2011). Peran sekolah ditunjukkan dengan adanya upaya pengembangan social emosional, dan moral dalam membentuk sikap social pada siswa terintegrasi dalam kegiatan pembelajaran. Beberapa penelitian menunjukkan bahwa kecerdasan emosional berpengaruh signifikan terhadap pembentukan sikap social siswa sekolah dasar (Siti Anisah et al., 2021). Perkembangan emosi berkorelasi positif terhadap perkembangan social anak (Ilham, 2020), dan perkembangan social emosional anak berkorelasi positif terhadap proses interaksi social yang dilakukan anak (Agustini et al., 2019). Pada lembaga pendidikan lain, peran aktif dewan sekolah dalam menegakkan kedisiplinan siswa melalui tata tertib sekolah memiliki kaitan yang signifikan terhadap pembentukan sikap disiplin siswa (Faiz et al., 2021). Bagaimana mengajarkan empati pada siswa (Swan, 2021). Bagaimana menstimulus siswa melaksanakan proses pengambilan keputusan terkait pilihan moral (Hardecker et al., 2019). pada intinya adalah membentuk sikap social siswa yang baik identic dengan mencetak anak berakhlakul karimah agar mereka mampu menyesuaikan diri dengan lingkungannya dan menentukan masa depannya sesuai tantangan zaman (Parhan, 2020).

\section{Kesimpulan}

Perkembangan social, emosional, dan moral merupakan satu kesatuan utuh yang akan berimplikasi pada pembentukan sikap social siswa. Pengembangan aspek-aspek tersebut tentu saja tidak terjadi secara alamiah, dalam aspek pedagogi, aspek social, emosi, dan moral bisa diajarkan melalui pembiasaan, internalisasi nilai-nilai karakter, 
modeling, bahkan di treatment terintegrasi dalam mata pelajaran. Di dukung oleh lingkungan keluarga, lingkungan sekolah, Masyarakat, dan budaya yang baik yang bisa dijadikan sumber belajar. Bantuan pendidik sebagai orang dewasa mutlak penting. tugas pendidik adalah membimbing dan mengarahkan agar potensi siswa berkembang maksimal.

Agar kemampuan sosialisasi anak meningkat, tugas pendidik adalah membimbing dan mengarahkan mereka untuk belajar menerima dan melaksanakan tanggung jawab, belajar bersaing dengan orang lain, belajar berprilaku social yang baik, belajar bekerja sama, belajar dari orang dewasa, belajar kepada kelompok sebaya, belajar menyesuaikan diri dengan standar kelompok, belajar bermain mengembangkan fisiknya, belajar berbagi, dan belajar bersikap sportif. Yang paling utama adalah pola asuh yang baik dari orang tua sebagai madrasah pertama bagi anak-anaknya dalam menjadikan anak yang berakhlakul karimah sebagai wujud sikap social yang baik dalam lingkungan masyarakat. Sikap social terwujud sebagai hasil dari proses pendampingan pendidik dalam mengembangkan tugas-tugas perkembangan siswa kearah kematangan.

\section{Referensi}

Agustini, N. K., Sujana, I. W., \& Adnyana Putra, I. K. (2019). Korelasi Antara Kecerdasan Emosional dengan Interaksi Sosial Siswa Kelas V SD Gugus VI Pangeran Diponegoro Denpasar Barat. Jurnal Pedagogi Dan Pembelajaran, 2(1), 131. https://doi.org/10.23887/jp2.v2i1.17620

Ahsani, E. L. F. (2020). Analisis Bahan Ajar Kurikulum 2013 Berbasis Multiple Intelligence Kelas IV. 8, 19-36.

Anisah. (2011). Pola Asuh Orang Tua Dan Implikasinya Terhadap Pembentukan Karakter Anak. Jurnal Pendidikan Universitas Garut, 5(1), 70-84.

Assingkily, M. S., \& Hardiyati, M. (2019). Analisis Perkembangan Sosial-Emosional Tercapai dan Tidak Tercapai Siswa Usia Dasar. Al-Aulad: Journal of Islamic Primary Education, 2(2), 19-31. https://doi.org/10.15575/al-aulad.v2i2.5210

Berlian, S., Rosmawati, \& Abu Assyari. (2015). Analisis Jenis-jenis Kenakalan Siswa SD Bahtera Makmur Kecamatan Bagan Sinembah. Jurnal Ilmu Pendidikan, 2(1), 1-13.

Faiz, F. R. F., Nurhadi, \& Rahman, A. (2021). Pembentukan Sikap Disiplin Siswa Pada Sekolah Berbasis Asrama. Qalamuna - Jurnal Pendidikan, Sosial, Dan Agama, 13(2), 309-326. https:/ / doi.org/10.37680/qalamuna.v13i2.902

Hardecker, S., Buryn-Weitzel, J. C., \& Tomasello, M. (2019). Adult instruction limits children's flexibility in moral decision making. Journal of Experimental Child Psychology, 187(xxxx), 104652. https:/ / doi.org/10.1016/j.jecp.2019.06.005

Henri. (2018). Perkembangan Peserta Didik. In Angewandte Chemie International Edition, 6(11), 951-952.

https://new.detik.com. (2014, Okt 2014 07:05 WIB Senin, 13). Aksi Brutal di SD Bukittinggi Tak Sekedar Kenakalan Anak-anak. Retrieved from detiknews: 
https:/ / news.detik.com/berita/d-2716676/aksi-brutal-di-sd-bukittinggi-taksekadar-kenakalan-anak-anak

Ilham, I. (2020). Perkembangan Emosi Dan Sosial Pada Anak Usia Sekolah Dasar. ELMuhbib: Jurnal Pemikiran Dan Penelitian Pendidikan Dasar, 4(2), 162-180. https:// doi.org/10.52266/el-muhbib.v4i2.562

Kemendikbud. (2013). Kurikulum 2013.

Ladubasari, Erna; Sriastria, W. (2012). Perkembangan Emosi Pada Anak Sekolah Dasar. Seminar Nasional FKIP UMC, 1-6.

Latifa, U. (2017). Aspek Perkembangan pada Anak Sekolah Dasar: Masalah dan Perkembangannya. 1(2).

Listyaningrum, D. (2018). Pengaruh Permainan radisional Gobak Sodor Terhadap Sikap Sosial Siswa Kelas III SDN 01 Manguharjo Kota Madiun. Gulawentah:Jurnal Studi Sosial, 3(2), 108. https:/ / doi.org/10.25273/gulawentah.v3i2.3463

Mandira, M. R., \& Stoltz, T. (2021). Bullying risk and protective factors among elementary school students over time: A systematic review. International Journal of Educational Research, 109(August 2020), 101838. https:// doi.org/10.1016/j.ijer.2021.101838

Parhan, M. (2020). Aktualisasi Peran Ibu Sebagai Madrasah Pertama Dan Utama Bagi Anak Di Era 4.0. JMIE (Journal of Madrasah Ibtidaiyah Education), 4(2), 157. https://doi.org/10.32934/jmie.v4i2.193

Peled, Y. (2019). Cyberbullying and its influence on academic, social, and emotional development of undergraduate students. Heliyon, 5(3), e01393. https:// doi.org/10.1016/j.heliyon.2019.e01393

Puspitasari, D., Widodo, H. P., Widyaningrum, L., Allamnakhrah, A., \& Lestariyana, R. P. D. (2021). How do primary school English textbooks teach moral values? A critical discourse analysis. Studies in Educational Evaluation, 70(July), 101044. https://doi.org/10.1016/j.stueduc.2021.101044

Sabani, F. (2019). Perkembangan Anak - Anak Selama Masa Sekolah Dasar (6 - 7 Tahun). Didakta: Jurnal Kependidikan, 8(2), 89-100.

Siti Anisah, A., Katmajaya, S., \& Zakiyyah, W. L. (2021). Pengaruh Kecerdasan Emosional Terhadap Sikap Sosial Pada Siswa Sekolah Dasar. Jurnal Pendidikan UNIGA, 15(1), 434. https:// doi.org/10.52434/jp.v15i1.1178

Sumani. (2019). Upaya Guru dalam Menangani Perilaku Kenakalan Siswa SD. Prosiding Seminar Nasional Pendidikan Program Pascasarjana Universitas PGRI Palembang, 909917.

Swan, P. (2021). The lived experience of empathic engagement in elementary classrooms: Implications for pedagogy. Teaching and Teacher Education, 102, 103324. https:// doi.org/10.1016/j.tate.2021.103324

Syaodih, E. (2003). Perkembangan anak taman kanak-kanak. Perkembangan Anak Taman Kanak-Kanak PERKEMBANGAN, 1-25.

Syukri, R. A., Bahri, A., Khaltsum, U., \& Makassar, U. M. (2021). Penerapan Model 
Pembelajaran Fun Learning Dalam Meningkatkan Hasil Belajar Menulis Karangan Narasi Siswa Sekolah Dasar. Jurnal Ilmu Pendidikan Dasar Indonesia, 1(1), 51-60. https:// doi.org/10.51574/judikdas.v1i1.212

Wiratman, A., Mustaji, M., \& Widodo, W. (2019). The effect of activity sheet based on outdoor learning on student's science process skills. Journal of Physics: Conference Series, 1157(2), 022007. https:/ / doi.org/10.1088/1742-6596/1157/2/022007

Zahro, A. M. (2018, Januari 2). Apa Yang Dimaksud Sikap Sosial. Retrieved from dictio: https://www.dictio.id/t/apa-yang-dimaksud-dengan-sikap-sosial/14919 
80 | Ani Siti Anisah, Sapriya, Kama Abdul Hakam, dan Ernawulan Syaodih

--- Halaman ini sengaja dikosongkan --- 